\title{
Viral Genetic Evolution in Host Cells Supports Tumorigenesis
}

\author{
Daniel A Achinko* \\ University City Science Center, USA
}

Submission: March 01, 2017; Published: March 23, 2017

"Corresponding author: Daniel A Achinko, University City Science Center, PepVax, Inc.10411 Motor City Drive Bethesda, MD 20817, Immage Biotherapeutics Corp, 3711 Market St. 8th Floor, Philadelphia, PA 19104, USA, Email: da4815@gmail.com, daniel.achinko@howard.edu

\begin{abstract}
Cancer genetics now associates several virus types to the disease. Six main viruses are considered underlying pathogenic agents of cancer and more of them are DNA viruses while a few are RNA retroviruses. The role of viruses in cancer is still elusive though several host cell genetic expression patterns, regulatory mechanisms and genetic variations have been identified and associated with related viral activity. Viruses are different in the type of genetic material they carry but what makes them common to severe disease situations could be their ability to integrate host genome, hence exploiting the host transcription and translation factors to drive their replication and encapsulation of genetic information for delivery out of the cell. The variation of these viruses in different cancer types and their evolutionary history with specificity to immune target cells could be of therapeutic importance if these mechanisms are well understood.
\end{abstract}

\section{Background}

Viruses are considered the smallest organisms and known to bemetabolically inert out of a host cell but become active when they integrate and infect a host cell in order to reproduce. In the absence of a host cell, viruses exist as a capsid or a protein coat and at times within a membrane. Viral genetic material could be DNA or RNA enclosed within the capsid and encoding viral elements [1]. Viruses cause mild to severe diseases and sometimes result in epidemic outbreaks observed for Ebola in 2014 and Zika in 2016 [2]. The role of viruses in cancers has undergone several experimental analyses over the years and now, recent evidence shows that at least 6 viruses contribute to human malignancies and they include but not limited to: human papilloma virus (HPV), Epstein-Barr virus (EBV), human T-cell lymphotropic virus (HTLV-1), Hepatitis C virus (HCV), Kaposi's associated sarcoma virus (KSHV) and Hepatitis B virus (HBV) [3]. These viruses contribute to about 10 to $15 \%$ of worldwide cancers with about 1.3 million fatalities occurring annually [4]. These human tumor viruses differ in the content of their genetic material with some identified as DNA related viruses (EBV, HPV, HBV, KSHV) while the others are RNA related viruses (HTLV1 and HCV). The difference in genetic material could suggest different entry patterns used by viruses to penetrate their host and how they regulate host cell transcription machinery for their individual pathogenic gains.

Despite the identification of cancer several years ago, their association to viral infection etiology remained a challenge until experimental analysis was able to show that, a virus was an agent with transmission capacity after filtration [5], hence leading to the identification of Rous sarcoma virus (RSV), and an avian virus that infected chickens [6]. It was considered the first identified tumor retrovirus transmitting chicken leukemia. Human warts were also associated with a viral etiology which only got recognition several years later wherein wart viruses also known as papilloma viruses were associated with cancer [7]. The identification and description of a B-cell malignancy in a Ugandan child was associated with a viral etiology and later called Burkitt's lymphoma [8]. Epstein-Barr virus was a different kind of herpesvirus, later identified through electron microscopy as the pathogen associated with Burkitt's lymphoma [9]. Laboratory analysis of several cancer types now links EBV to different cancer types including: gastric carcinoma, nasopharyngeal carcinoma, several cases of Hodgkins's lymphoma and B-cell lymphoma in patients who are immune compromised [10,11]. Viral etiology to hepatitis went from being a suspicion because of its infectious mode of transmission, to the identification of a blood antigen as a surface protein of DNA viruses [12], shown to react with antibodies from hepatitis patients [13], hence called hepatitis B virus. Studies now associate HBV to hepatocellular carcinoma (HCC) resulting to about three hundred and fifty million infected individuals and three hundred thousand deaths, annually [14]. The advancement of genetic technology and research analysis to further understand viral roles in tumorigenesis led to the discovery of HTLV-1, HCV and KSHV during the 1980s and 1990s. 
HCV infected patients were identified to possess an RNA virus agent with a transmission pattern different from HBV and shown to infect more than 270 million people yearly with about 4-7\% of them evolving to HCC [15]. HTLV-1 was identified in cultured human T-cell lymphoma cells. Between 10-20\% of individuals are infected annually by HTLV-1 and prognosis still remains elusive. KSHV affects less than $10 \%$ compared to $90 \%$ of individuals infected annually in the USA and Africa respectively. KSHV as a variation of hepesvirus happens to be the most common form associated with several cancer typesand its related KS lesions generally occur in connective tissues below the skin further evolving in some cases to angiproliferative tumors [3].

Not all cancers are caused by viruses but from the discovery and evolutionary observation of viruses within cells, it is clear that viral associated cancerscould involve several cell types within the body and their targets could be dominantly immune cells as seen for B-cell related viruses with genetic mechanisms associated with immortality of the cell and also T-cell related viruses inhibiting normal immune function. Almost all cancer types do not stimulate an immune response due to the identification of genes as "self" but viruses either stimulate intense immune response leading to cancer cells like HCC or down-regulate major histocompatibility class I and II genes expression and cell transport mechanism required for presenting HLA class I \& II viral antigenic peptides to immune cells [2]. The ability of viruses to inhibit host immune response means they have evolutionarily learned host transcription malfunction associated with tumorigenesis, hence using it to successfully proliferate in cells. If the genetic pattern of integration of viral genetic material into host DNA and regulation of transcription and translation mechanism is well understood, then we could be closer to therapies that cut across cancer types.

\section{Conclusion}

Viral genetics and cancer formation is an intense area of research and herpesviruses and related cancers have been targeted through several forms of therapy. The ability of a given virus type like EBV, found to be associated with different cancer types, to infect different cell types, suggest different genetic regulatory patterns within the host cell, which is well orchestrated by the virus. These patterns could strongly depend on how the virus integrates into the host genome and taking control of transcription and translation processes. Underlying knowledge of this process will be of great therapeutic importance.

\section{References}

1. Emiliani C (1993) Extinction and viruses. BioSystems 31(2-3): 155159.

2. Achinko DA, Dormer A, Narayanan M (2016) Identification of genetic pathways driving Ebola virus disease in humans and targets for therapeutic intervention [version 1; referees: awaiting peer review] F1000Research 5: 2810.

3. Martin D, Gutkind JS (2009) Human tumor-associated viruses and new insights into the molecular mechanisms of cancer. Oncogene 27(Suppl 2): S31-S42.

4. Parkin DM (2006) The global health burden of infection-associated cancers in the year 2002. Int J Cancer 118(2): 3030-3044

5. Levine AJ (2001) The Origins of Virology. In: Knipe DM, Howley PM (Eds.), Fields virology, $\left(4^{\text {th }}\right.$ edn) Philadelphia: Lippincott Williams \& Wilkins, PP. 3-18.

6. Rous P (1910) A transmissible avian neoplasm (sarcoma of the common fowl). J Exp Med 12(5): 696-705.

7. Ciuffo G (1907) Innesto positivo con filtrato di verruca volgare. Giorn Ital Mal Venereol 48: 12-7

8. Burkitt D (1962) A children's cancer dependent on climatic factors. Nature 194: 232-234.

9. Epstein MA, Henle G, Achong BG, Barr YM (1965) Morphological and biological studies on a virus in cultured lymphoblasts from Burkitt's lymphoma. J Exp Med 121(5): 761-770.

10. Javier RT, Butel JS (2008) The history of tumor virology. Cancer Res 68(19): 7693-7706.

11. Hirschman RJ, Shulman NR, Barker LF, Smith KO (1969) Virus-like particles in sera of patients with infectious and serum hepatitis. JAMA 208(9): 1667-1670.

12. Blumberg BS (1977) Australia antigen and the biology of hepatitis B. Science 197(4298): 17-25.

13. Kao JH, Chen DS (2002) Global control of hepatitis B virus infection. Lancet Infect Dis 2(7): 395-403.

14. Thomas DL, Astemborski J, Rai RM, Anania FA, Schaeffer M, et al (2000) The natural history of hepatitis C virus infection: host, viral, and environmental factors. JAMA 284(4): 450-456.

15. Poiesz BJ, Ruscetti FW, Gazdar AF, Bunn PA, Minna JD, et al. (1980) Detection and isolation of type $C$ retrovirus particles from fresh and cultured lymphocytes of a patient with cutaneous T-cell lymphoma. Proc Natl Acad Sci USA 77(12): 7415-7419.

\begin{tabular}{l} 
Your next submission with JuniperPublishers \\
will reach you the below assets \\
- Quality Editorial service \\
- Swift Peer Review \\
- Reprints availability \\
- E-prints Service \\
- Manuscript Podcast for convenient understanding \\
- Global attainment for your research \\
- Manuscript accessibility in different formats \\
( Pdf, E-pub, Full Text, audio) \\
- Unceasing customer service \\
Track the below URL for one-step submission \\
https://juniperpublishers.com/online-submission.php \\
\hline
\end{tabular}

